\title{
INSTRUCTIONAL MEDIA USED IN TEACHING ENGLISH
}

\author{
Silvi Aisyah ${ }^{1}$, Acep Haryudin ${ }^{2}$ \\ ${ }^{1}$ IKIP Siliwangi \\ ${ }^{2}$ IKIP Siliwangi \\ ${ }^{1}$ silviaisyah@student.ikipsiliwangi.ac.id, ${ }^{2}$ haryacep@gmail.com
}

\begin{abstract}
This study investigates (1) the use of instructional media by teachers in teaching English to students. This research was conducted at a private elementary school in Cimahi, namely the Harapan Bangsa Creative Elementary School. To collect data, researchers used a case study approach with observation and interview techniques. The results showed that there are three types of learning media that are generally used by teachers, consisting of: (1) books (2) pictures and (3) videos. Each of these media is used in many different ways according to the needs of teaching and learning activities. In this case the teacher feels difficult to face challenges in the process of selecting and using instructional media due to lack of resources and enthusiasm from students so that teaching and learning activities become less effective and efficient. The solution used to solve the problem of learning media during the selection process is to utilize the media available at school. In the field observation process, the media that has been used by the teacher is a textbook. From the use of instructional media using textbooks only $75 \%$ of students are able to survive with these media.
\end{abstract}

Keywords: Instructional Media, English

\section{INTRODUCTION}

Learning media is a tool to help the course of learning effectively and practically so that learning can be carried out smoothly and in accordance with regulations. Learning media or teaching materials are very important to be used in the world of education, especially in the teaching and learning process at school. Haryudin. A, Yana, and Efransyah (2020) states that in the learning process at school, learning media is important in the teaching and learning process in the classroom. learning media can be understood as something that can convey messages from existing sources in a planned manner, so that a conducive learning process occurs where the recipient can carry out the teaching and learning process efficiently and effectively. Ristyani $\mathrm{N}$. A, Nurhayati, and Husnussalam (2019) stated that the media is a tool used by teachers in learning and makes teaching and learning process effective. whereas Wahyuni E.S, and Yokhebed (2019) state that learning media are tools or tools used to help convey information in teaching and learning activities. Learning media in the teaching and learning process is very important in order to be able to provide motivation and student interest in following the process of teaching and learning activities, providing a pleasant experience so that student learning outcomes can be improved.

According to Harmer (2007) in (Laksono E.I, Damayanti, and Santoso 2019) stated that there are several types of learning media, namely: textbooks, pictures, projectors, whiteboards, powerpoints, videos and computer-based technology tools. Learning media has two components, namely software and hardware trimmer, on the software media a teacher can use an application while on the hardware media a teacher can use a computer, laptop or projector. 
Based on the statement above, it can be concluded that the learning media is very important to be used in helping the teaching and learning process in the classroom so that the activities run effectively and efficiently so that students can feel comfortable and interested in participating in the teaching and learning process at school. Therefore, the presence of learning media can increase student interest in teaching and learning and can help teachers deliver material through media taught to students, with many types of learning media will certainly facilitate teachers in teaching and learning so that teachers can choose the type of media that will used in accordance with the material.

English is the language used as the official communication medium in many countries which can be understood and used widely by the whole world. According to Parmawati (2018) language is a role in various aspects of development to achieve success from students who can learn all subjects. Foreign languages are usually taught as school subjects for the purpose of communicating with foreigners or to read printed material in English. English is also one of the subjects used starting from elementary, junior high and high school levels. Maudini. A, and Nurhasanah (2018) stated that English is the language learned in Indonesia, most of the students can learn English. Based on the statement above, it can be concluded that language is the role used as a communication medium for the success of students who can learn it.

The purpose of this study, namely:

1. To find out the use of instructional media by teachers in teaching English.

\section{METHOD}

This study uses a case study approach that aims to capture certain events and real situations that exist in primary schools without the direct involvement of the researcher. Ali. KM, and JJ. Evans (2019) states that case studies can discuss the general problem of the facts being occur, without having literature, and influenced by positive results. Whereas Abidin. J, and Fahmi (2019) stated that the case study is a research that aims to reveal an event with rational and indepth research. This research was conducted in one elementary school in the Cimahi area, West Java. Participants are students and teachers of English from the school. Teachers involved in this study did not have special requirements, except teachers only used instructional media in teaching and learning activities in class.

To collect data, this study uses observation and interviews. Even this observation is a nonparticipant observation, in which the researcher is only a complete observer. This observation aims to examine what learning media are used by teachers and find out what learning media are used in teaching and learning activities. This observation was made once when the teacher taught in class. Meanwhile, the interview was conducted informally. Informal interviews are used to check whether information obtained from observations is appropriate or not. However, questions can be developed according to the needs of researchers.

\section{RESULTS AND DISCUSSION}

\section{Results}

Based on field observations, the media that have been used are textbooks. during learning, first the class feels very conducive to students who listen and write when the teacher delivers the material, however after that the class feels not conducive because many students enter and exit the class, disturbing friends, noisy, sleepy and do not want to be quiet. The problem is using textbooks can make students feel unfocused in the teaching and learning process, too monotonous and make students feel bored more quickly. The solution to overcoming the 
problem of learning media is that a teacher will attract students 'attention to refocus on learning by adding points to students' daily values. however with this incident there were about $75 \%$ of students who were able to stay with the media.

\section{Discussion}

1. Use of Instructional Media by Teachers in Teaching English

A teacher seems to have to have as many skills and resources as possible in the classroom to make students have a higher level of innate knowledge so that they become skilled and competent. One effective source in the learning process is using media. Researchers conducted research in one private school in Cimahi grade 3, this school is accustomed to using media in the teaching and learning process in class. Based on the results of the interview, the media commonly used in the teaching and learning process are text books, pictures and videos. As for other additional media such as blackboards, projectors, and so on. The teacher applies the textbook media according to the material being taught, for example material about "something that is in the house" then the material used is in accordance with the theme in the textbook. Teachers at this school use textbooks because they can have benefits, such as being able to assist students in implementing the curriculum because it is structured according to the applicable curriculum, giving students the opportunity to repeat lessons or learn new material. The next learning media used by teachers in teaching is pictures. The picture is used as a tool to facilitate the teacher in explaining the material to students. For example, when the material being taught is Things at Home, the teacher will bring pictures that fit the theme such as pictures of cabinets, mattresses, chairs, sofas, decorative lamps, tables, kitchen utensils and so on. So when the teacher explains the material with pictures, students will find it easier to accept it. The next learning media is in the form of video but the media is rarely used due to limited resources, whereas of course this aims to explain the material to students so that students are more interested and excited when teaching and learning activities. Because in the video there is a picture that runs so indirectly students can capture the material and remember it by watching and listening at the same time.

Following are the results of an interview with one of the English language educators at Harapan Bangsa Elementary School:

Interview results table

\begin{tabular}{|c|c|c|}
\hline No. & Questions & Answers \\
\hline 1. & What is your full name Mrs? & Elma Pravita Dewi, S.Pd \\
\hline 2. & $\begin{array}{l}\text { How long have you been teaching in } \\
\text { this school? }\end{array}$ & 5 Month \\
\hline 3. & $\begin{array}{l}\text { What are motivated you to become an } \\
\text { English teacher? }\end{array}$ & $\begin{array}{l}\text { Liked English and reasons teaching } \\
\text { elementary school because I have feeds } \\
\text { different }\end{array}$ \\
\hline 4. & $\begin{array}{l}\text { Before becoming a teacher at this } \\
\text { school, have you ever been a teacher at } \\
\text { another school? }\end{array}$ & Not yet \\
\hline 5. & $\begin{array}{l}\text { During Mrs teaching, what's the } \\
\text { subject interesting about the English } \\
\text { language? }\end{array}$ & $\begin{array}{l}\text {-Vocabulary } \\
\text {-Things in classroom } \\
\text {-Demontrative pronoun }\end{array}$ \\
\hline 6. & $\begin{array}{l}\text { During Mrs Teaching, what was the } \\
\text { most memorable experience in the } \\
\text { classroom? }\end{array}$ & $\begin{array}{l}\text { Students find out themselves about the } \\
\text { material. }\end{array}$ \\
\hline
\end{tabular}




\begin{tabular}{|c|c|c|}
\hline 7. & $\begin{array}{l}\text { Were there any unpleasant experiences } \\
\text { while you were teaching? }\end{array}$ & $\begin{array}{l}\text { There is, when indeed students are } \\
\text { difficult to manage }\end{array}$ \\
\hline 8. & $\begin{array}{l}\text { So far what material have you } \\
\text { conveyed in English learning } \\
\text { materials? }\end{array}$ & $\begin{array}{l}\text {-Alfhabet } \\
\text {-Have or Has sentences } \\
\text {-Abilities }\end{array}$ \\
\hline 9. & $\begin{array}{l}\text { Do you use teaching learning media or } \\
\text { not? }\end{array}$ & Using learning media \\
\hline 10. & $\begin{array}{l}\text { If yes, what media are often used when } \\
\text { teaching class? }\end{array}$ & Textbooks, Pictures, and Videos \\
\hline 11. & $\begin{array}{l}\text { What are the strengths of the media, so } \\
\text { Mrs often use them in class? }\end{array}$ & $\begin{array}{l}\text { Students more quickly understand the } \\
\text { material }\end{array}$ \\
\hline 12. & What classes do you teach? & Grades 3,5 and 6 \\
\hline 13. & $\begin{array}{l}\text { Are there any difficulties using the } \\
\text { media? }\end{array}$ & There is \\
\hline 14. & $\begin{array}{l}\text { What are the difficulties experienced } \\
\text { by Mrs in applying the media in the } \\
\text { class? }\end{array}$ & $\begin{array}{l}\text { Students feel not focused on the } \\
\text { material but more focused on the media }\end{array}$ \\
\hline 15. & $\begin{array}{l}\text { What solution do you do when you find } \\
\text { difficulties in applying the media? }\end{array}$ & $\begin{array}{l}\text { More interesting students' attention to } \\
\text { refocus on learning }\end{array}$ \\
\hline 16. & Is the lack of the media? & $\begin{array}{l}\text { For textbooks are too monotonous and } \\
\text { make students feel bored }\end{array}$ \\
\hline 17. & $\begin{array}{l}\text { How do students respond when using } \\
\text { the media? }\end{array}$ & $\begin{array}{l}\text { Good enough, students more easily } \\
\text { absorb material }\end{array}$ \\
\hline 18. & $\begin{array}{l}\text { How do you prepare the media in the } \\
\text { classroom? }\end{array}$ & $\begin{array}{l}\text { For alphabet material invites students } \\
\text { to sing together first after that enter the } \\
\text { core material }\end{array}$ \\
\hline 19. & $\begin{array}{l}\text { How far are the students' abilities in } \\
\text { participating in learning English using } \\
\text { these media? }\end{array}$ & $\begin{array}{l}\text { Students understand faster and students } \\
\text { feel enthusiastic }\end{array}$ \\
\hline 20. & $\begin{array}{l}\text { What is the condition of the classroom } \\
\text { when students take part in learning } \\
\text { English using these media? }\end{array}$ & Excited and very crowded \\
\hline 21. & $\begin{array}{l}\text { What are the characteristics of students } \\
\text { in grade } 3 \text { ? }\end{array}$ & $\begin{array}{l}\text { Tend to be more active (ask more } \\
\text { questions), more willing to try to open } \\
\text { their own dictionary }\end{array}$ \\
\hline 22. & $\begin{array}{l}\text { What is the strategy used in teaching } \\
\text { using these media? }\end{array}$ & $\begin{array}{l}\text { The first relaxes students to calm down } \\
\text { after previous learning then provides } \\
\text { entertainment by singing }\end{array}$ \\
\hline 23. & $\begin{array}{l}\text { What are the inhibiting and supporting } \\
\text { factors in maximizing learning? }\end{array}$ & $\begin{array}{l}\text { Sometimes the use of video media is a } \\
\text { power failure }\end{array}$ \\
\hline 24. & $\begin{array}{l}\text { Does teaching English use learning } \\
\text { methods? }\end{array}$ & Of course \\
\hline 25. & What method do you use? & PAIKEM \\
\hline 26. & $\begin{array}{l}\text { Do you often give assignments / } \\
\text { homework to students? }\end{array}$ & $\begin{array}{l}\text { It's often enough that students practice } \\
\text { a lot at home }\end{array}$ \\
\hline 27. & $\begin{array}{l}\text { Are there students who complain about } \\
\text { teaching and learning processes in the } \\
\text { classroom about English material? }\end{array}$ & $\begin{array}{l}\text { Nothing, instead students ask for more } \\
\text { and want to try using other media }\end{array}$ \\
\hline
\end{tabular}




\begin{tabular}{lll}
\hline 28. & $\begin{array}{l}\text { Are the lessons delivered memorable } \\
\text { for the students and you? }\end{array}$ & Sometimes \\
\hline 29. & $\begin{array}{l}\text { Are there English subjects that are } \\
\text { difficult to convey to students? }\end{array}$ & $\begin{array}{l}\text { There is no because the material is still } \\
\text { basic }\end{array}$ \\
\hline $\begin{array}{l}\text { What is your expectation in improving } \\
\text { learning in the classroom using }\end{array}$ & -by using the media, students will \\
learning media so that students are & - students are more enthusiastic about \\
more active and easier to understand? & $\begin{array}{l}\text { learning by using media } \\
\text {-students are more active and willing to } \\
\text { try themselves about the material to be } \\
\text { studied }\end{array}$ \\
\hline
\end{tabular}

Based on the table above, the use of media is very important and indeed has become a very important thing when the learning process. This was expressed directly by one of the educator organizations who did get involved directly in the teaching and learning process.

The use of media is very good and positive impact in the teaching and learning process. In accordance with the results of questions number eleven and thirty which stated that "students understand more quickly about the material" also "by using the media, students will better understand the subject matter". Support from the media which is very influential in the process of absorption and understanding of the material. In addition, the use of media can increase student learning enthusiasm. This enthusiasm gives rise to encouragement to students to try new things. Students become more inclined to use media in every learning, especially in media videos. This is shown by the questions at number twenty-seven and thirty with the results of an interview stating "Nothing, students ask for more and want to try to use other media" also "students are more enthusiastic about learning by using media".

The existence of media that helps in the learning process of students increases motivation in learning, so that children do not get bored easily in the process of teaching and learning. This is based on the results of a teacher interview stating "students understand quickly and students feel enthusiastic".

As for the large impact on the use of media, students become independent in terms of learning. This is expressed based on the answers given in question number thirty which states that "students are more active and willing to try themselves about the material to be studied". The positive impact certainly does not escape also from the negative impacts arising from the use of dating media. Some of the negative impacts arising from learning using media are divided focus, books that become a monotonous means of using instructional media, and require power that can stop at any time and cause the learning media to die. This is expressed in answers number fourteen, sixteen, and twenty-seven which state that "students feel they are not focused on the material but are more focused on the media", "for textbooks are too monotonous and make students feel bored", and "sometimes use the constraints of video media is power failure". However, the existence of this negative thing certainly triggers a teacher to be more creative and innovative in carrying out the teaching and learning process in the classroom.

\section{CONCLUSION}

The use of instructional media by teachers in one elementary school in Cimahi still needs to be improved and developed. It was proven from schools that there was still a lack of media such as limited projectors. In addition, there are still many technology-based media today that need to be tried by teachers so that not only print and image media are used. With the limitations of 
the media provided in schools, it is hoped that the regional government will pay more attention to the provision of learning media in elementary schools in Cimahi equally. Teachers are expected to frequently attend educational seminars related to instructional media, which are expected to improve the quality of teacher teaching as experience progresses. The teacher must use technology-based media so that students do not feel monotonous and bored. It is hoped that by using technology-based media students can foster a higher sense of learning English than using media that is commonly used. The purpose of all this is to help students get better results in learning English.

\section{ACKNOWLEDGMENTS}

Alhamdulillah, Lord of the world who has given Grace and Blessing to researchers in completing this journal. Greetings and greetings to the Prophet Muhammad, his family and colleagues, and us as his people. It is an honor to thank all the lecturers, family and friends who have contributed in various ways so that this research paper is processed and becomes a full article to be presented to the IKIP Siliwangi campus in fulfillment of part of the requirements for a bachelor's degree in S.Pd (S- 1) education in English education.

\section{REFERENCES}

Abidin, J., \& Fahmi, I. (2019). Media Sosial Dalam Mempengaruhi Perilaku Keberagamaan Siswa Dan Solusinya Melalui Pendidikan Agama Islam. Wahana Karya Ilmiah, 3(01).

Alpi, K. M., \& Evans, J. J. (2019). Distinguishing Case Study as a Research Method from Case Reports As A Publication Type. Journal of The Medical Library Association: Jmla, 107(1), 1.

Haryudin, A., Yana, Y., \& Efransyah, E. (2020). An Analysis of Developing English Teaching Materials at the Vocational High School in Cimahi. Jurnal Ilmiah P2m Stkip Siliwangi, 7(1), 11-19.

Laksono, E. I., Damayanti, E., \& Santoso, I. (2019). Students'perception Towards The Application of Social Media Instagram as an Instructional Media. Project (Professional Journal Of English Education), 2(4), 421-428.

Maudini, A., Nurhasanah, A., \& Mulyani, E. R. (2018). Different Learning Strategies Preference Among Senior High School Students of Different Programs. Project (Professional Journal of English Education), 1(6), 769-774.

Parmawati, A. (2018). The Study Correlation Between Reading Habit And Pronunciation Ability At The Second Grade Students Of Ikip Siliwangi. Eltin Journal, Journal Of English Language Teaching In Indonesia, 6(1), 46-52.

Ristyani, N. A., \& Nurhayati, N. N. (2020). Improving Students'interest By Using Picture Media At Tk Nur Assalam. Project (Professional Journal of English Education), 3(1), 14.

Wahyuni, E. S., \& Yokhebed, Y. (2019). Deskripsi Media Pembelajaran Yang Digunakan Guru Biologi Ssma Negeri Di Kota Pontianak. Jurnal Pendidikan Informatika Dan Sains, 8(1), 32-40. 